\title{
A Survey of U.S. Medical School Full-Time Faculty Members Age 55+ One-fifth are caregivers and most report caregiving strain
}

Kimberly Ann Skarupski ( $\sim$ kskarupski@jhmi.edu )

Johns Hopkins University School of Medicine https://orcid.org/0000-0002-6722-6181

David L Roth

Johns Hopkins University

Samuel C Durso

Johns Hopkins University School of Medicine

\section{Research}

Keywords: caregiving, faculty development, academic medicine, workforce

Posted Date: May 15th, 2020

DOI: https://doi.org/10.21203/rs.3.rs-26857/v1

License: (1) (i) This work is licensed under a Creative Commons Attribution 4.0 International License.

Read Full License 


\section{Abstract}

Background Nearly one-third of medical school faculty members are age 55+. As the global population ages, the prevalence of family caregiving is increasing, yet we know very little about the caregiving experiences of aging faculty members in academic medicine. Faculty caregiving responsibilities coupled with projected physician shortages and burnout will likely impact the workforce. We examined the prevalence of caregiving and concomitant caregiving strain and well-being differences between aging, male and female medical school faculty members.

Methods We analyzed data from a survey of 2,126 full-time medical school faculty $55+$ years of age conducted in 2017. We used chi-square tests of independence and independent samples t-tests to calculate statistical differences between groups.

Results Of the faculty members invited to participate, $40.8 \%$ completed the survey $(\mathrm{N}=2,126)$. Most were male $(1,425 ; 67.2 \%)$, white $(1,841 ; 88.3 \%)$, and married/partnered $(1,803 ; 85.5 \%)$. The mean age was 62.3 years. Of this sample, $19.0 \%$ reported providing care on an on-going basis to a family member, friend, or neighbor with a chronic illness or disability $(17.3 \%[n=242]$ of the 1,425 males and $22.4 \%[n=$ 154] of female respondents). Among the 396 caregiving faculty members, $90.2 \%$ reported experiencing some or a lot of mental or emotional strain from caregiving. Compared to their female faculty caregiver counterparts, males were older (mean age 62.3 years vs. 60.0) and more likely to be married and not living alone.

Conclusion These data highlight caregiving responsibilities and significant concomitant mental or emotional strain of a significant proportion of U.S. medical schools' rapidly aging workforce. Human resource leaders in academic medicine should increase attention to these expanding needs.

\section{Background}

By 2030, the proportion of adults in the United States (U.S.) age 65 + will be $21 \%$ compared to $16 \%$ in 2018 [1]. Similarly, our medical schools' faculty populations are growing older numerically and proportionally. In U.S. Liaison Committee on Medical Education (LCME)-accredited medical schools in 2019 , the average age of all full-time faculty members $(N=178,871)$ was 49.1 years [2] compared to 44.7 years in 1987 [3] and faculty members who were age 55 or older comprised $31 \%$ of the full-time medical school faculty population in 2019 [2] compared to 19\% in 1987 [3]. For comparison, adults age 55 or older constituted $28.5 \%$ of the entire U.S. population in 2017 [4].

As populations age, caregiving needs also rise. In the gerontologic literature, it is well known that family and unpaid caregivers provide the majority of care for older adults [5, 6]. According to the 2015 Bureau of Labor Statistics, it was estimated that during $2013-2014,16.1 \%$ of the U.S. civilian noninstitutionalized population age 15 and older provided unpaid care to someone age 65 or older [7]. Because full-time, older faculty members in medical schools are predominantly male [1], it might be assumed that caregiving 
responsibilities and associated caregiving strain are not a high priority among older faculty members; however, there is little published data on this topic.

Caregiving and caregiving burden affect employee wellness and productivity [8-9]. With increased awareness of both current and projected growth in caregiving responsibilities among their faculty members, human resource and faculty affairs and development leaders may develop appropriate policies, programs, and resources. In this report, we sought to determine the prevalence of caregiving among late-career male and female faculty members in academic medicine and the associated caregiving strain and well-being.

\section{Methods}

The data for these analyses come from a survey of 2,126 full-time faculty age 55 and older at 14 U.S. LCME-accredited medical schools from May-September, 2017, as reported in our previous work $[10,11]$. We obtained standard sociodemographic data via self-report, including: sex; age; race (eight categories: American Indian/Alaskan Native; Asian; Black or African; Hispanic, Latino, Spanish; Multiracial/ethnic; Native Hawaiian or other Pacific Islander; Other; White); marital status (three categories: single, never married; single, separated, divorced, or widowed; and partnered or married; number of people in the household; and personal finances (finances sufficient, finances not sufficient, unsure).

As we began to develop the survey instrument to describe the status of late-career faculty in academic medicine and their work-life expectations, we hypothesized that both caregiving and general well-being would be associated with work-life expectations and retirement decisions. To minimize overall survey burden, we constrained our caregiving items to three validated questions adapted from previous research [12]: (1) Are you currently providing care on an on-going basis to a family member, friend, or neighbor with a chronic illness or disability (Yes, No, prefer not to answer); (2) Does the person for whom you provide on-going care currently live with you? (Yes, No, prefer not to answer); and (3) How much of a mental or emotional strain is it on you to provide this care? (No strain, Some strain, A lot of strain, prefer not to answer).

As a rudimentary assessment of general well-being, we asked six, single-item standard questions: (1) In general, would you say your health is excellent, very good, good, fair, or poor?; (2) During the past week, for much of the time I felt depressed (Yes, No); (3) How often do you get the social and emotional support you need? (Always, Usually, Sometimes, Rarely, Never); (4) How would you rate your quality of life? (Very good, Good, Neither good nor poor, Poor, Very poor); and (5) I find comfort in my religion or spirituality many times a day, every day, most days, some days, once in awhile, never/almost never, not applicable. As reported previously [8], we also asked questions about retirement and included one of those questions in the current analyses - Have you thought about or begun to think about retiring from full-time employment in academic medicine? (Yes, Unsure - maybe 5 years, Unsure - maybe 10 years, No).

The study was approved by the American Institutes for Research's institutional review board. Survey respondents were informed-both in the introductory email from their institution's faculty affairs and 
development office leaders and in the survey instructions-that the survey was anonymous, that participation was voluntary, and that they could skip any question.

We tabulated the univariate statistics for the total population $(N=2,126)$ and conducted the chi-square test of independence and independent samples t-tests for statistical differences between two caregiving groups: providing care, and not providing care; and between males and females. We analyzed data using The Statistical Package for the Social Sciences (SPSS) for Windows (version 24, Chicago, Illinois).

\section{Results}

The total number of full-time faculty 55 or older in the 14 participating institutions surveyed was 5,204 . Of these, 2,126 faculty members $(40.8 \%)$ responded. The majority of the survey respondents were male $(67.2 \%)$ and the average age of the survey respondents was 62.3 (standard deviation [SD] = 5.4; range = 55-88) (Table 1). Most respondents were White (88.3\%) and partnered or married (85.5\%). More than half $(61.1 \%)$ lived in a two person household and $27.9 \%$ reported three or more people in the household. Nearly three-quarters $(70.6 \%)$ reported that their finances were sufficient.

The majority of respondents reported that in general, their health was either excellent (43.8\%) or very good (38.9\%). The majority (92.3\%) reported that they did not feel depressed during much of the time in the past week. The majority reported getting the social and emotional support they need usually (52.4\%) or always $(24.4 \%)$. The majority also rated their quality of life as good $(33.5 \%)$ or very good $(59.7 \%)$. There was wide variability in the reporting of finding comfort in religion or spirituality, with more than onethird (39.3\%) finding comfort most days, every day, or many times a day and more than one-quarter $(28.4 \%)$ reporting 'not applicable.' Almost half $(45.2 \%)$ reported having thought about or begun thinking about retiring from full-time employment, $19.6 \%$ reported being unsure, but maybe within five years, and $24.7 \%$ were unsure, but maybe within ten years. Ten percent $(10.5 \%)$ reported that they had not thought about retirement.

Among those who answered the caregiving question $(n=2,086)$, nineteen percent $(n=396)$ reported providing care on an on-going basis to a family member, friend, or neighbor with a chronic illness or disability, equating to $22.4 \%$ of the female faculty members and $17.3 \%$ of the male faculty members. On average, compared to those who reported not having caregiving responsibilities, the caregiving faculty members were significantly $(p<0.05)$ more likely to be: younger (mean age 61.4 vs. 62.5$)$; living in slightly larger households ( $40.0 \%$ of caregivers lived in households of $3+$ people vs. $25.0 \%$ not caregiving); and less likely to be financially secure $(63.0 \%$ of caregivers reported that their finances were secure vs. $73.0 \%$ of those not caregiving). Caregiving faculty members were also statistically less likely than their noncaregiving counterparts to report that: their health was excellent (37.7\% vs. $45.4 \%)$; they always get the social and emotional support they need ( $16.1 \%$ vs. $26.2 \%)$; and that their quality of life was very good ( $49.1 \%$ vs. $62.1 \%)$. However, caregiving faculty members were more likely to report that they find comfort in their religion or spirituality any times a day or every day (32.6\% vs. $24.2 \%)$ compared to their noncaregiving counterparts. 
There were no statistically significant differences between caregivers and non-caregivers regarding thoughts about retirement; an equal proportion of caregivers and non-caregivers (45.4\% and $45.6 \%$, respectively), reported having thought about or begun thinking about retiring from full-time employment in academic medicine.

Among those who answered the caregiving strain question $(n=388)$, approximately one-quarter $(21.6 \%)$ reported that providing care was associated with a lot of mental or emotional strain; $68.6 \%$ reported some strain, and $9.8 \%$ reported no strain. Comparing male and female caregivers, approximately equal proportions of males and females reported similar levels of strain. Male caregivers were older than female caregivers (62.3 vs. 60.0 ), more likely to be married ( $95.4 \%$ vs. $72.8 \%$ ), and lived in slightly larger households (2.6 mean number of people in the household vs. 2.3). There were no other statistically significant differences in finances, self-reported health, depression, social support, quality of life, religiosity, or thoughts about retirement.

\section{Discussion}

We found high rates of both caregiving and caregiving-related strain among late-career faculty members in medical schools. In this report, we found that nearly one-fifth (19\%) of the full-time faculty members age 55 or older reported providing care for someone on an on-going basis. This rate is somewhat higher than the overall national average of $16 \%$ [7] and the $12 \%$ rate found in a previous national epidemiologic survey that used a similar caregiving status question [12]. Interestingly, we also found that a sizeable proportion of men in our study (17.3\%) reporting caregiving roles compared to $22.4 \%$ of women faculty members. Caregiving is often characterized as a role predominantly taken by women [7], but this gender difference may be diminishing. Indeed, Wolff et al. [13] found in longitudinal national samples, that more men are taking on family caregiving roles in more recent surveys, especially for non-dementia caregiving. This trend should inform our traditional caregiving services and programs as we evaluate their acceptance among male caregivers, as well as medical school faculty members.

We also found that $90 \%$ percent of the caregivers reported experiencing some or a lot of mental or emotional strain providing care. This rate of caregiving strain is also higher than the reported rate in a previous national epidemiologic survey [12] - 33\% of 5,159 caregivers in the Roth et al. (2009) study reported no caregiving-related strain compared to $10 \%$ reporting no strain in our sample.

Caregiving and caregiving strain in particular, are known to have negative effects on caregiver physical, mental, and social health [14-19]. For example, in the Roth et al. (2009) study of 43,099 communitydwelling adults (average age $65.5, S D=9.8$ ), those who reported high caregiving strain had poorer quality of life than less-strained caregivers and non-caregivers [12]. Similarly, we also found that caregiving faculty members were less likely to report: excellent health; adequate social and emotional support; and very good quality of life than their non-caregiving counterparts. In secondary analyses (not reported here), we found that the faculty caregivers who reported a lot of strain were nearly twice as likely to report 
depression as caregivers who reported only some strain and that more caregiver strain was also inversely associated with happiness, social and emotional support, good quality of life.

We also observed that caregivers in our study were statistically more likely to report finding comfort in their religion or spirituality every day compared to their non-caregiving peers. There was a similar trend for reporting every day comfort in religion or spirituality among the no strain group, although not statistically significant. There is literature showing association between daily spiritual experiences and better selfrated health and social networks [20] and a known association between religiosity/spirituality and life satisfaction [21]. Further exploration of this topic may generate innovative faculty development interventions around caregiving, social support, and coping.

There are several limitations to this study. First, our findings are from a convenience sample of faculty from only 14 of the 145 LCME-accredited U.S. medical schools and may not be generalizable to faculty at any individual medical school. Second, these cross-sectional data were collected during a snapshot in time in 2017 , and the response rate was only $41 \%$. Third, our well-being items were self-report, single-item questions and our caregiving and caregiving strain items were similarly brief. Furthermore, we did not examine the nature or intensity of the faculty members' caregiving experiences, which is very important. For example, in their recent analysis of national trends in family caregiving between 1999 and 2015, Wolff et al. (2017) found that the primary caregivers were overwhelmingly spouses and adult children [13]. They observed that caregiving arrangements lasted four years or longer on average and that primary caregivers provided approximately 30 hours of care per week. Although untested, we may hypothesize that faculty members' caregiving efforts are equally significant. Similarly, we did not examine the association of the caregiving experience with the work experience, other than correlating caregiving with thinking about retirement. For example, in their systematic review of the international research on unpaid caregivers and labor market choices, Lilly, Laporte, and Coyte (2007) found that 'heavilyinvolved/intensive' caregivers were more likely to withdraw from the labor market than their counterparts [23]. Although the data vary, in general, most studies have shown a moderate reduction in the number of hours worked per week among caregivers and an inverse association between caregiving intensity and hours worked per week.

Our findings illuminate the necessity for more in-depth investigation of older faculty members' needs, particularly as these needs impact work performance or as the needs either hasten or impede career transition decisions, including retirement. For example, are older, caregiving faculty members with increasing caregiving strain less likely to: submit grant applications; conduct research; spend time in clinic; spend time mentoring junior faculty members? Are older, caregiving faculty members with increasing strain more likely to: retire; have worse mental or physical health; abuse substances; behave badly toward colleagues, trainees, or patients; make more clinical errors? These questions and more require further research.

The caregiving responsibilities and associated caregiving-related strain experienced by a sizeable proportion of our faculty population present ample opportunity for collaboration between human 
resource offices, wellness programs, and faculty development offices to address current and future employee caregiving-work conflicts and responsibilities. Many of our institutions already offer a variety of resources and there are myriad programs in the community; for example: respite care; sitter/companion programs; home health/visiting nurses; meal preparation; shopping services; chore/task services; financial planning; caregiver-focused web-based interventions [22]; and online/virtual support groups (e.g., Facebook, Instagram, Twitter). However, there is little evidence documenting the utilization and impact of these programs on faculty outcome measures, such as well-being and burnout or institutional outcomes, such as recruitment, retention, faculty satisfaction, promotion, or retirement. Efforts to develop new programs, tailor existing programs, and then market them specifically to late-career faculty who are caregivers may help to normalize the aging experience, minimize perceived stigma, and increase the likelihood of utilization and positive outcomes.

\section{Conclusion}

The medical school faculty population is rapidly aging. One-third of all full-time medical school faculty members are 55 years or older [3]. In our home institution, we have 3,017 full-time faculty in the school of medicine and $28.9 \%$ (872) are 55 years or older. There is no mandatory retirement for medical school faculty [24] and coupled with the estimated physician shortage in the next ten years [25], faculty may remain in the workforce longer than in previous decades, driving-up the faculty population age even more rapidly than anticipated. Furthermore, life expectancy is also increasing. For example, an average American woman at age 65 is expected to live another 20.5 years and a man age 65 , another 18 years [26]. Correspondingly, faculty members and their care recipients are living longer, necessitating even more care. Additionally, lower fertility rates have reduced the number of available family member caregivers [27]; hence, our future aging faculty members may have an even greater likelihood of serving as caregivers to their spouses and a lower likelihood of reliance on children to provide or assist with caregiving.

Caregiving needs inevitably increase as our population grows older and lives longer. Our data highlight the caregiving responsibilities and concomitant mental or emotional strain and well-being of a significant proportion of the U.S. medical schools' rapidly aging workforce. Faculty affairs and development leaders and human resource offices should increase attention to these expanding needs.

\section{Declarations}

\section{Ethical approval:}

American Institutes for Research (the institution serving to provide ethical approval for Association of American Medical College research) approved this research: reference number EX00421.

\section{Consent for publication}


The authors consent publication.

\section{Availability of data and materials}

The data that support the findings of this study are available from the Association of American Medical Colleges (AAMC) but restrictions apply to the availability of these data, which were used under license for the current study, and so are not publicly available. Data are however available from the authors upon reasonable request and with permission of the AAMC.

\section{Competing interests:}

The authors have no competing interests.

\section{Funding:}

None reported.

\section{Authors' contributions:}

Dr. Skarupski conducted the data analyses and was the primary author. Drs. Roth and Durso contributed to the conceptual review and editing of the manuscript. All authors read and approved the final manuscript.

\section{Acknowledgements:}

The authors would like to thank Valerie Dandar, MA, director of medical school operations, academic affairs and Valarie Clark, MPA, former Director of Constituent Engagement at the Association of American Medical Colleges, for their expertise in project and data management.

\section{References}

1. QuickFacts. United States [Internet]. U.S. Census Bureau. U.S. Census Bureau; [cited 2019 Jun 26]. Available from: https://www.census.gov/quickfacts/fact/table/US\#viewtop.

2. Faculty Roster - Data and Analysis - AAMC [Internet]. Association of American Medical Colleges. [data request and email correspondence, February 20, 2020]. Available from: https://www.aamc.org/data/facultyroster/.

3. Alexander H, Qi Liu C. The Aging of Full-time U.S. Medical School Faculty: 1967-2007. AAMC Analysis In Brief. 2009 Oct;9(4).

4. Annual Estimates of the Resident Population for Selected Age Groups by Sex for the United States. States, Counties, and Puerto Rico Commonwealth and Municipios: April 1, 2010 to July 1, 2017 
[Internet]. American FactFinder - Results. U.S. Census Bureau; 2018 [cited 2019 Jun 11]. Available from: https://factfinder.census.gov/faces/tableservices/jsf/pages/productview.xhtml? pid=PEP_2017_PEPAGESEX\&prodType=table.

5. Freedman VA, Spillman BC. Disability and care needs among older Americans. The Milbank Quarterly. 2014;92(3):509-41.

6. Schulz R, Eden J. Families Caring for an Aging America. Washington, DC: The National Academies Press; 2016.

7. Unpaid eldercare in the United States. 2013-2014 [Internet]. U.S. Bureau of Labor Statistics. U.S. Bureau of Labor Statistics; 2016 [cited 2019 May 14]. Available from: https://www.bls.gov/news.release/archives/elcare_09232015.htm.

8. Gaugler JE, Pestka DL, Davila H, Sales R, Owen G, Baumgartner SA, et al. The Complexities of Family Caregiving at Work: A Mixed-Methods Study. The International Journal of Aging Human Development. 2018;87(4):347-76.

9. Buffardi LC, Smith JL, O'Brien AS, Erdwins CJ. The impact of dependent-care responsibility and gender on work attitudes. J Occup Health Psychol. 1999;4(4):356-67.

10. Skarupski KA, Welch C, Dandar V, Mylona E, Chatterjee A, Singh M. Late-Career Expectations: A Survey of Full-Time Faculty Members Who Are 55 or Older at 14 U.S. Medical Schools. Academic Medicine. 2019 Jun 18.

11. Skarupski KA, Dandar VA, Mylona EA, Chatterjee AA, Welch CA, Singh MA. Late-Career Faculty: A Survey of Faculty Affairs and Faculty Development Leaders of U.S. Medical Schools. Academic Medicine. 2019 Jun 18.

12. Roth DL, Perkins M, Wadley VG, Temple EM, Haley WE. Family caregiving and emotional strain: associations with quality of life in a large national sample of middle-aged and older adults. Qual Life Res. 2009;18(6):679-88.

13. Wolff JL, Mulcahy J, Huang J, Roth DL, Covinsky K, Kasper JD. Family Caregivers of Older Adults, 1999-2015: Trends in Characteristics, Circumstances, and Role-Related Appraisal. Gerontologist. 2018;58(6):1021-32.

14. Pinquart $M$, Sörensen S. Differences between caregivers and noncaregivers in psychological health and physical health: A meta-analysis. Psychol Aging. 2003;18(2):250-67.

15. Schulz R, O'Brien AT, Bookwala J, Fleissner K. Psychiatric and Physical Morbidity Effects of Dementia Caregiving: Prevalence, Correlates, and Causes. Gerontologist. 1995;35(6):771-91.

16. Brummett BH, Babyak MA, Siegler IC, Vitaliano PP, Ballard EL, Gwyther LP, et al. Associations among perceptions of social support, negative affect, and quality of sleep in caregivers and noncaregivers. Health Psychol. 2006;25(2):220-5.

17. Haley WE, West CAC, Wadley VG, Ford GR, White FA, Barrett JJ, et al. Psychological, social, and health impact of caregiving: A comparison of Black and White dementia family caregivers and noncaregivers. Psychol Aging. 1995;10(4):540-52. 
18. Mausbach BT, Patterson TL, Grant I. Is depression in Alzheimers caregivers really due to activity restriction? A preliminary mediational test of the Activity Restriction Model. J Behav Ther Exp Psychiatry. 2008;39(4):459-66.

19. Neugaard B, Andresen E, Mckune SL, Jamoom EW. Health-Related Quality of Life in a National Sample of Caregivers: Findings from the Behavioral Risk Factor Surveillance System. Journal of Happiness Studies. 2008;9(4):559-75.

20. Skarupski KA, Fitchett G, Evans DA, Mendes de Leon CF. Daily spiritual experiences in a biracial, community-based population of older adults. Aging Mental Health. 2010;14(7):779-89.

21. Elliott M, Hayward RD. Religion and Life Satisfaction Worldwide: The Role of Government Regulation. Sociology of Religion. 2009;70(3):285-310.

22. Ploeg J, Ali MU, Markle-Reid M, Valaitis R, Bartholomew A, Fitzpatrick-Lewis D, et al. CaregiverFocused, Web-Based Interventions: Systematic Review and Meta-Analysis (Part 2). Journal of Medical Internet Research. 2018;20(10):e11247.

23. Lilly MB, Laporte A, Coyte PC. Labor Market Work and Home Cares Unpaid Caregivers: A Systematic Review of Labor Force Participation Rates, Predictors of Labor Market Withdrawal, and Hours of Work. The Milbank Quarterly. 2007;85(4):641-90.

24. Weinberg SL, Scott MA. The Impact of Uncapping of Mandatory Retirement on Postsecondary Institutions. Educational Researcher. 2013;42(6):338-48.

25. Dall T, Reynolds R, Jones K, Chakrabarti R, lacobucci W. The Complexities of Physician Supply and Demand: Projections from 2017 to 2032: 2019 Update. Washington, DC: Association of American Medical Colleges; https://aamcblack.global.ssl.fastly.net/production/media/filer_public/31/13/3113ee5c-a038-4c16-89af294a69826650/2019_update_-_the_complexities_of_physician_supply_and_demand__projections_from_2017-2032.pdf. Published April, 2019. Accessed April 27, 2020.

26. National Center for Health Statistics. 2016, Health, United States, 2015: With special feature on racial and ethnic health disparities, Hyattsville, MD.

27. Seltzer JA, Bianchi SM. Demographic Change and Parent-Child Relationships in Adulthood. Annu Rev Sociol. 2013;39:275-90.

\section{Abbreviations}

AAMC - Association of the American Medical Colleges

LCME - Liaison Committee on Medical Education

SPSS - Statistical Package for the Social Sciences

U.S. - United States

\section{Tables}




\begin{tabular}{|c|c|c|c|c|c|c|c|}
\hline \multirow[t]{2}{*}{ Table 1. Characteristics of sample $(\mathrm{N}=2,126)$} & \multirow{2}{*}{$\begin{array}{c}\text { Total } \\
\text { Number } \\
\text { (\%) }\end{array}$} & \multicolumn{3}{|c|}{$\begin{array}{c}\text { Providing Care? } \\
(\mathrm{N}=2,086)\end{array}$} & \multicolumn{3}{|c|}{$\begin{array}{c}\text { Caregivers } \\
(\mathrm{N}=396)\end{array}$} \\
\hline & & $\begin{array}{c}\text { Yes }(n=396) \\
{[19.0 \%]}\end{array}$ & $\begin{array}{c}\text { No } \\
(n=1690) \\
{[81.0 \%]}\end{array}$ & $\begin{array}{c}p \\
\text { value }\end{array}$ & $\begin{array}{l}\text { Males } \\
(\mathrm{n}=242) \\
{[61.1 \%)}\end{array}$ & $\begin{array}{l}\text { Females } \\
(\mathrm{n}=154) \\
{[28.9 \%]}\end{array}$ & $\begin{array}{c}p \\
\text { value }\end{array}$ \\
\hline $\begin{array}{l}\text { Sex } \\
\qquad \text { Male } \\
\text { Female }\end{array}$ & $\begin{array}{r}1425 \\
(67.2) \\
697 \\
(32.8)\end{array}$ & $\begin{array}{l}242(17.3) \\
154(22.4)\end{array}$ & $\begin{array}{r}1153 \\
(82.7) \\
534 \\
(77.6)\end{array}$ & .006 & -- & -- & \\
\hline $\begin{array}{l}\text { Does the care recipient live with you? } \\
\text { Yes } \\
\text { No }\end{array}$ & -- & $\begin{array}{l}115(29.5) \\
275(70.5)\end{array}$ & -- & -- & $\begin{array}{r}76 \\
(31.7) \\
164 \\
(68.3)\end{array}$ & $\begin{array}{r}39 \\
(26.0) \\
111 \\
(74.0)\end{array}$ & .232 \\
\hline $\begin{array}{l}\text { How much of a mental or emotional strain is it on you to } \\
\text { provide this care? } \\
\text { A lot of strain (total: } 84[21.6 \%] \text { ) } \\
\text { Some strain (total: } 266[68.6 \%] \text { ) } \\
\text { No strain (total: } 38[9.8 \%] \text { ) }\end{array}$ & -- & $\begin{array}{r} \\
84(21.6) \\
266(68.6) \\
38(9.8)\end{array}$ & -- & - & $\begin{array}{r}52 \\
(21.8) \\
161 \\
(67.4) \\
26 \\
(10.9)\end{array}$ & $\begin{array}{r} \\
32 \\
(21.5) \\
105 \\
(70.5) \\
12(8.1)\end{array}$ & .644 \\
\hline $\begin{array}{l}\text { Age categories } \\
\begin{array}{l}55-59 \\
60-64 \\
65-69 \\
70-74 \\
75+ \\
\\
\text { mean }(S D)\end{array}\end{array}$ & $\begin{array}{r}753 \\
(36.0) \\
738 \\
(35.3) \\
389 \\
(18.6) \\
148(7.1) \\
61(2.9) \\
62.3(5.4)\end{array}$ & $\begin{array}{r}152(39.2) \\
155(39.9) \\
59(15.2) \\
17(4.4) \\
5(1.3) \\
61.4(4.8)\end{array}$ & $\begin{array}{r}584 \\
(35.1) \\
569 \\
(34.2) \\
325 \\
(19.6) \\
130(7.8) \\
54(3.2) \\
\\
62.5 \\
(5.5)\end{array}$ & .002 & $\begin{array}{r}78 \\
(33.1) \\
92 \\
(39.0) \\
46 \\
(19.5) \\
16(6.8) \\
4(1.7) \\
\\
62.3 \\
(5.3)\end{array}$ & $\begin{array}{r}74 \\
(48.7) \\
63 \\
(41.4) \\
13(8.6) \\
1(0.7) \\
1(0.7) \\
\\
60.0 \\
(3.7)\end{array}$ & $<.001$ \\
\hline $\begin{array}{l}\text { Race/Ethnicity } \\
\text { White } \\
\text { Asian } \\
\text { Hispanic } \\
\text { Black } \\
\text { Others }\end{array}$ & $\begin{array}{r}1841 \\
(88.3) \\
131(6.3) \\
55(2.6) \\
28(1.3) \\
30(1.4)\end{array}$ & $\begin{array}{r}339(86.0) \\
23(5.8) \\
14(3.6) \\
9(2.3) \\
9(2.3)\end{array}$ & $\begin{array}{r}1478 \\
(89.2) \\
102(6.2) \\
41(2.5) \\
17(1.0) \\
19(1.1)\end{array}$ & .067 & $\begin{array}{r}207 \\
(85.9) \\
15(6.2) \\
11(4.6) \\
3(1.2) \\
5(2.1)\end{array}$ & $\begin{array}{r}132 \\
(86.3) \\
8(5.2) \\
3(2.0) \\
6(3.9) \\
4(2.6)\end{array}$ & .287 \\
\hline $\begin{array}{l}\text { Marital status } \\
\text { Partnered or married } \\
\text { Single (separated, divorced, widowed) } \\
\text { Single (never married) }\end{array}$ & $\begin{array}{r}1803 \\
(85.5) \\
216 \\
(10.2) \\
91(4.3)\end{array}$ & $\begin{array}{r}339(86.7) \\
36(9.2) \\
16(4.1)\end{array}$ & $\begin{array}{r}1431 \\
(85.1) \\
176 \\
(10.5) \\
75(4.5)\end{array}$ & .710 & $\begin{array}{r}229 \\
(95.4) \\
7(2.9) \\
4(1.7)\end{array}$ & $\begin{array}{r}110 \\
(72.8) \\
29 \\
(19.2) \\
12(7.9)\end{array}$ & $<.001$ \\
\hline
\end{tabular}


Page 12/14 


\begin{tabular}{|c|c|c|c|c|c|c|c|}
\hline \multirow[t]{2}{*}{ Characteristics } & \multirow{2}{*}{$\begin{array}{c}\text { Total } \\
\\
\text { Number } \\
\text { (\%) }\end{array}$} & \multicolumn{3}{|c|}{$\begin{array}{l}\text { Providing Care? } \\
\qquad(\mathrm{N}=2,086)\end{array}$} & \multicolumn{3}{|c|}{$\begin{array}{l}\text { Caregivers } \\
\qquad(\mathrm{N}=396)\end{array}$} \\
\hline & & $\begin{array}{c}\text { Yes }(n=396) \\
{[19.0 \%]}\end{array}$ & $\begin{array}{c}\text { No } \\
(n=1690) \\
{[81 \%]}\end{array}$ & $\begin{array}{c}p \\
\text { value }\end{array}$ & $\begin{array}{c}\text { Males } \\
(n=242) \\
{[61.1 \%)}\end{array}$ & $\begin{array}{c}\text { Females } \\
(n=154) \\
{[28.9 \%]}\end{array}$ & $p$ value \\
\hline $\begin{array}{l}\text { Number of people in household } \\
1 \\
2 \\
3+ \\
\quad \text { mean }(S D)\end{array}$ & $\begin{array}{r}228 \\
(11.0) \\
1270 \\
(61.1) \\
580 \\
(27.9) \\
2.3(0.9)\end{array}$ & $\begin{array}{l} \\
\\
34(8.7) \\
200(51.3) \\
156(40.0) \\
2.5(1.0)\end{array}$ & $\begin{array}{l}191 \\
(11.6) \\
1048 \\
(63.4) \\
414(25.0) \\
2.3(0.9)\end{array}$ & $\begin{array}{l}<.001 \\
<.001\end{array}$ & $\begin{array}{r}9(3.8) \\
130 \\
(54.2) \\
101 \\
(42.1) \\
2.6 \\
(1.0)\end{array}$ & $\begin{array}{r}25 \\
(16.7) \\
70 \\
(46.7) \\
55 \\
(36.7) \\
2.3(1.0)\end{array}$ & $\begin{array}{r}<.001 \\
.008\end{array}$ \\
\hline $\begin{array}{l}\text { Personal finances } \\
\text { Finances sufficient } \\
\text { Finances not sufficient } \\
\text { Unsure }\end{array}$ & $\begin{array}{r}1490 \\
(70.6) \\
253 \\
(12.0) \\
367 \\
(17.4)\end{array}$ & $\begin{array}{r} \\
249(63.0) \\
65(16.5) \\
81(20.5)\end{array}$ & $\begin{array}{r}1224 \\
(73.0) \\
180(10.7) \\
272(16.2)\end{array}$ & $<.001$ & $\begin{array}{r}158 \\
(65.3) \\
36 \\
(14.9) \\
48 \\
(19.8)\end{array}$ & $\begin{array}{r}91 \\
(59.5) \\
29 \\
(19.0) \\
33 \\
(21.6)\end{array}$ & .452 \\
\hline $\begin{array}{l}\text { In general, would you say your health is? } \\
\text { Excellent } \\
\text { Very good } \\
\text { Good } \\
\text { Fair } \\
\text { Poor }\end{array}$ & $\begin{array}{r}892 \\
(43.8) \\
792 \\
(38.9) \\
287 \\
(14.1) \\
57(2.8) \\
8(0.4)\end{array}$ & $\begin{array}{r} \\
145(37.7) \\
153(39.7) \\
68(17.7) \\
17(4.4) \\
2(0.5)\end{array}$ & $\begin{array}{r}734(45.4) \\
622(38.5) \\
216(13.4) \\
38(2.4) \\
5(0.3)\end{array}$ & .009 & $\begin{array}{r}86 \\
(36.4) \\
101 \\
(42.8) \\
34 \\
(14.4) \\
13(5.5) \\
2(0.8)\end{array}$ & $\begin{array}{r}59 \\
(39.6) \\
52 \\
(34.9) \\
34 \\
(22.8) \\
4(2.7) \\
0(0)\end{array}$ & .083 \\
\hline $\begin{array}{l}\text { During the past week, for much of the time I felt } \\
\text { depressed. } \\
\text { Yes } \\
\text { No }\end{array}$ & $\begin{array}{r}156(7.7) \\
1887 \\
(92.3)\end{array}$ & $\begin{array}{r} \\
36(9.4) \\
349(90.6)\end{array}$ & $\begin{array}{r}116(7.2) \\
1500 \\
(92.8)\end{array}$ & .148 & $\begin{array}{r}19(8.1) \\
216 \\
(91.9)\end{array}$ & $\begin{array}{r}17 \\
(11.3) \\
133 \\
(88.7) \\
\end{array}$ & .286 \\
\hline $\begin{array}{l}\text { How often do you get the social and emotional } \\
\text { support you need? } \\
\text { Always } \\
\text { Usually } \\
\text { Sometimes } \\
\text { Rarely } \\
\text { Never }\end{array}$ & $\begin{array}{r}496 \\
(24.4) \\
1067 \\
(52.4) \\
347 \\
(17.1) \\
109(5.4) \\
16(0.8)\end{array}$ & $\begin{array}{r} \\
62(16.1) \\
202(52.6) \\
92(24.0) \\
26(6.8) \\
2(0.5)\end{array}$ & $\begin{array}{r} \\
424(26.2) \\
852(52.7) \\
247(15.3) \\
80(5.0) \\
13(0.8)\end{array}$ & $<.001$ & $\begin{array}{r}45 \\
(19.1) \\
118 \\
(50.2) \\
57 \\
(24.3) \\
13(5.5) \\
2(0.9)\end{array}$ & $\begin{array}{r}17 \\
(11.4) \\
84 \\
(56.4) \\
35 \\
(23.5) \\
13(8.7) \\
0(0)\end{array}$ & .152 \\
\hline
\end{tabular}




\begin{tabular}{|c|c|c|c|c|c|c|c|}
\hline \multirow[t]{2}{*}{ Characteristics } & \multirow{2}{*}{$\begin{array}{c}\text { Total } \\
\text { Number } \\
\text { (\%) }\end{array}$} & \multicolumn{3}{|c|}{$\begin{array}{c}\text { Providing Care? } \\
(\mathrm{N}=2,086)\end{array}$} & \multicolumn{3}{|c|}{$\begin{array}{c}\text { Caregivers } \\
(\mathrm{N}=396)\end{array}$} \\
\hline & & $\begin{array}{c}\text { Yes }(n=396) \\
{[19.0 \%]}\end{array}$ & $\begin{array}{c}\text { No } \\
(n=1690) \\
{[81 \%]}\end{array}$ & $\begin{array}{c}p \\
\text { value }\end{array}$ & $\begin{array}{c}\text { Males } \\
(n=242) \\
{[61.1 \%)}\end{array}$ & $\begin{array}{c}\text { Females } \\
(n=154) \\
{[28.9 \%]}\end{array}$ & $\begin{array}{c}p \\
\text { value }\end{array}$ \\
\hline $\begin{array}{l}\text { How would you rate your quality of life? } \\
\text { Very good } \\
\text { Good } \\
\text { Neither good nor poor } \\
\text { Poor } \\
\text { Very poor }\end{array}$ & $\begin{array}{r}1216 \\
(59.7) \\
682 \\
(33.5) \\
113 \\
(5.5) \\
21(1.0) \\
5(0.2) \\
\end{array}$ & $\begin{array}{r} \\
189(49.1) \\
154(40.0) \\
34(8.8) \\
7(1.8) \\
1(0.3) \\
\end{array}$ & $\begin{array}{r} \\
1005 \\
(62.2) \\
522 \\
(32.3) \\
74(4.6) \\
13(0.8) \\
3(0.2) \\
\end{array}$ & $<.001$ & $\begin{array}{r}121 \\
(51.5) \\
92 \\
(39.1) \\
21(8.9) \\
1(0.4) \\
0(0)\end{array}$ & $\begin{array}{r}68 \\
(45.3) \\
62 \\
(41.3) \\
13(8.7) \\
6(4.0) \\
1(0.7)\end{array}$ & .067 \\
\hline $\begin{array}{l}\text { I find comfort in my religion or spirituality } \\
\text { Many times a day } \\
\text { Every day } \\
\text { Most days } \\
\text { Some days } \\
\text { Once in awhile } \\
\text { Never/almost never } \\
\text { N/A }\end{array}$ & $\begin{array}{r}203 \\
(10.0) \\
326 \\
(16.0) \\
271 \\
(13.3) \\
236 \\
(11.6) \\
240 \\
(11.8) \\
183 \\
(9.0) \\
579 \\
(28.4) \\
\end{array}$ & $\begin{array}{r} \\
\\
\\
\\
\\
\\
43(11.2) \\
82(21.4) \\
46(12.0) \\
54(14.1) \\
40(10.4) \\
30(7.8) \\
89(23.2) \\
\end{array}$ & $\begin{array}{r} \\
157(9.7) \\
235 \\
(14.5) \\
222 \\
(13.7) \\
180 \\
(11.1) \\
195 \\
(12.0) \\
150(9.3) \\
482 \\
(29.7) \\
\end{array}$ & .004 & $\begin{array}{r}24 \\
(10.2) \\
50 \\
(21.2) \\
30 \\
(12.7) \\
32 \\
(13.6) \\
28 \\
(11.9) \\
22(9.3) \\
50 \\
(21.2)\end{array}$ & $\begin{array}{r}19 \\
(12.8) \\
32 \\
(21.6) \\
16 \\
(10.8) \\
22 \\
(14.9) \\
12(8.1) \\
8(5.4) \\
39 \\
(26.4)\end{array}$ & .539 \\
\hline $\begin{array}{l}\text { Have you thought about or begun to think about retiring from } \\
\text { full-time employment in academic medicine? } \\
\text { Yes } \\
\text { Unsure, maybe } 5 \text { years } \\
\text { Unsure, maybe } 10 \text { years } \\
\text { No }\end{array}$ & $\begin{array}{r}915 \\
(45.2) \\
397 \\
(19.6) \\
500 \\
(24.7) \\
213 \\
(10.5)\end{array}$ & $\begin{array}{r} \\
\\
174(45.4) \\
72(18.8) \\
93(24.3) \\
44(11.5)\end{array}$ & $\begin{array}{r}733 \\
(45.6) \\
319 \\
(19.9) \\
395 \\
(24.6) \\
159(9.9)\end{array}$ & .812 & $\begin{array}{r}113 \\
(48.5) \\
39 \\
(16.7) \\
57 \\
(24.5) \\
24 \\
(10.3)\end{array}$ & $\begin{array}{r}61 \\
(40.7) \\
33 \\
(22.0) \\
36 \\
(24.0) \\
20 \\
(13.3)\end{array}$ & .346 \\
\hline
\end{tabular}

